\title{
Sustainable Innovation System Using Process Of Bagasse Become Sodium Lignosulfonate Surfactant For Enhanced Oil Recovery
}

\author{
Rini Setiati ${ }^{1 *}$, Septoratno Siregar ${ }^{2}$, Taufan Marhaendrajana ${ }^{3}$, and Deana Wahyuningrum $^{4}$ \\ ${ }^{1}$ Petroleum Engineering, Trisakti University, PhD Student Petroleum Engineering. ITB, Bandung, Indonesia \\ ${ }^{2}$ Professor of Petroleum Engineering, ITB, Bandung, Indonesia \\ ${ }^{3}$ Assoc.Prof. of Petroleum Engineering, ITB, Bandung, Indonesia \\ ${ }^{4}$ Assoc.Prof. of Chemistry, ITB, Bandung, Indonesia
}

\begin{abstract}
The purpose of this research is to get new product innovation process from bagasse, that is Sodium LignoSulfonate surfactant. Lignosulfonates surfactants in petroleum engineering are used as injection fluids into oil reservoirs to increase oil recovery, which is known as Enhanced Oil Recovery process. Lignosulfonates is made of lignin as raw material, which can be extracted from bagasse as one of its sources. Bagasse contains $24-25 \%$ lignin, so it is sufficient to be processed into lignosulfonates. Today, bagasse is one of the biomass resources widely used as a boiler fuel in sugar factory, source of animal feed, material for paper, cement and brick reinforcement .This study presents an innovation of bagasse utilization. This innovation involves two scientific application fields, firstly, chemistry in the processing of bagasse into sodium lignosulfonates surfactant and secondly, petroleum engineering in the effort of using sodium lignosulfonates surfactant to increase oil production from the reservoir. The last stage in this process is injection of the sodium lignosulfonates surfactant into a synthetic core in laboratory scale use water and surfactant injection.. The amount of oil that is produced from the injected core shows the increase in oil yield from the sodium lignosulfonates surfactant injection.
\end{abstract}

\section{Introduction}

In specific, bagasse is scientifically defined as a waste of sugar cane liquid extraction after milling process and is in a fibrous form. The amount of bagasse production each year are abundant, easily obtained, and economical. Based on the data from Indonesian Sugar Farm Research Center (P3GI), bagasse amounts to approximately $32 \%$ of milled sugar cane weight or about 10,2 million ton/year all around Indonesia.Furthermore, Bagasse contains 48-52\% water, sugar at an average of $3,3 \%$, and fiber at an average of $47,7 \%$. Also, bagasse fiber is undissolvable in water and it consists of cellulose, pentosan and lignin. In essence, Lignin is the raw material, which is processed through sulfonation before subsequently turning to surfactant. Thus, the product is classified as Surfactant Sodium Lignosulfonate. In addition, Lignosulfonate is one of the variants of anionic surfactant that is often utilized in a chemical injection process of EOR (Enhanced Oil Recovery) in the oil industry. High lignin content is what makes bagasse eligible candidate for surfactant. Today, bagasse is one of the biomass resources widely used as a boiler fuel in sugar factory, source of animal feed, material of paper, cement and brick reinforcement material. Sustainable innovation process from bagasse can be done by isolation process and sulphonation process into SLS surfactant. The result of chemical process can be applied as an injection fluid to increase oil recovery.

\section{Methods}

\footnotetext{
Corresponding author: rinisetiatidgm@gmail.com
}

In this study, the innovation of bagasse processing is made in a gradual and sustainable system. This innovation includes the processing of bagasse into sodium lignosulfonates surfactant and using sodium lignosulfonates surfactant as an injection fluid in enhanced oil recovery . Figure 1 show the processing of bagasse into lignosulfonates can be done in two stages: lignin separation process from bagasse (isolation process) and lignin sulfonation process into lignosulfonates. In the lignin isolation stage, bagasse and $2 \%$ sodium hydroxide was refluxed directly for five hours, followed by diluting the filtrate sodium hydroxide with distilled water at $1: 1$ volume ratio. Then, $\mathrm{H}_{2} \mathrm{SO}_{4}$ is added in drops until $\mathrm{pH}$ equals 2 and the resulting solution is precipitated for at least eight hours and the precipitate is filtered and dried, and the solid obtained is lignin. The bagasse lignin is then compared with the commercial lignin (from Aldrich and Kraft) and characterized by FTIR spectrophotometry, which identifies the functional groups contained in the lignin from the isolation process.

The next process is sulfonating lignin into lignosulfonates using $0.1 \mathrm{M}$ sodium bisulfite and refluxed at $150{ }^{\circ} \mathrm{C}$ for five hours while stirring with a magnetic stirrer. Then the precipitate is filtered, and the solid is dried to obtain sodium lignosulfonates surfactant. The next process is testing the surfactant with FTIR and NMR to determine the structure of the sulfonate group.The test is performed as a screening of sodium lignosulfonates surfactant, which is followed by characterization of the sodium lignosulfonates surfactant consisting of compatibility test, phase behavior test, middle emulsion test, adsorption test, IFT test and wettability test. 


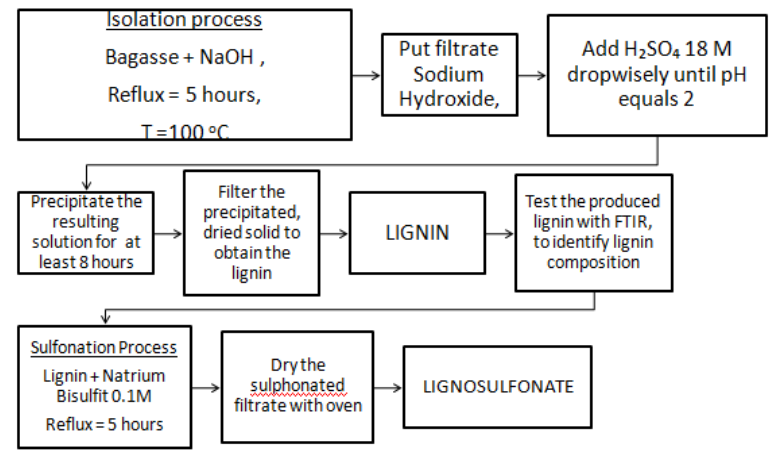

Fig. 1. Schematic processing of bagasse into SLS surfactant

Lignosulfonates surfactants in petroleum engineering are used as injection fluids into oil reservoirs to increase oil recovery, which is known as Enhanced Oil Recovery process. Currently, the lignosulfonates surfactants which are widely used have petroleum base, known as petroleum sulfonate. Since it uses petroleum as raw material, its price also follows oil price which is relatively expensive. Lignosulfonates is made of lignin as raw material, which can be extracted from bagasse as one of its sources. Bagasse contains $24-25 \%$ lignin, so it is sufficient to be processed into lignosulfonates. High lignin content is what makes bagasse potential candidate for lignosulfonates surfactant. Today, bagasse is one of the biomass resources widely used as a boiler fuel in sugar factory, source of animal feed, material for paper, cement and brick reinforcement. This study presents an innovation of bagasse utilization. This innovation involves two scientific application fields, firstly, chemistry in the processing of bagasse into sodium lignosulfonates surfactant and secondly, petroleum engineering in the effort of using sodium lignosulfonates surfactant to increase oil production from the reservoir. This innovation process is optimized gradually and continuously in order to obtain maximum results.

Based on the characteristic test, followed by core injection process. The last stage in this process is injection of the sodium lignosulfonates surfactant into a synthetic core in laboratory scale. The core injection process consists of two stages: water injection, which is followed by sodium lignosulfonates surfactant injection (surfactant flooding). The amount of oil that is produced from the injected core by water and surfactant shows the increase in oil yield from the sodium lignosulfonates surfactant injection. Figure 2 showed scheme of surfactant injection for EOR process

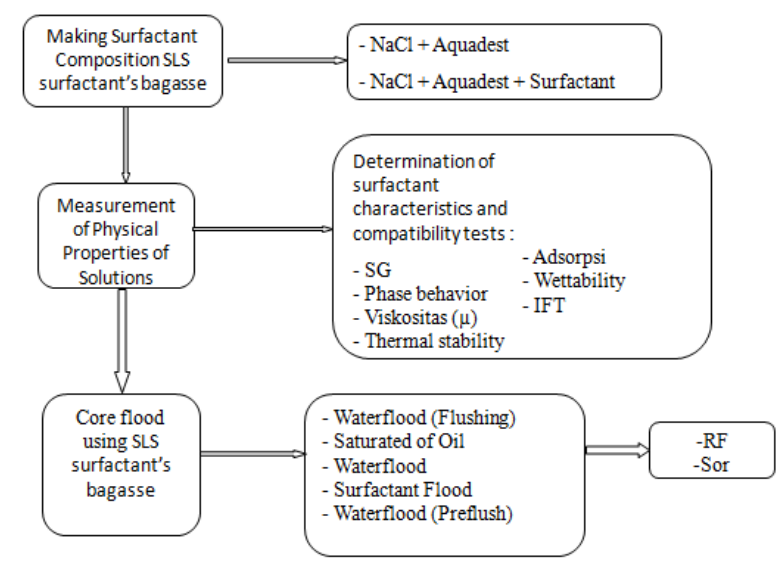

Fig. 2.Scheme of surfactant injection for EOR process

Figure 3 below showed process activity of bagasse into SLS surfactant and its application as injection fluid in EOR process.

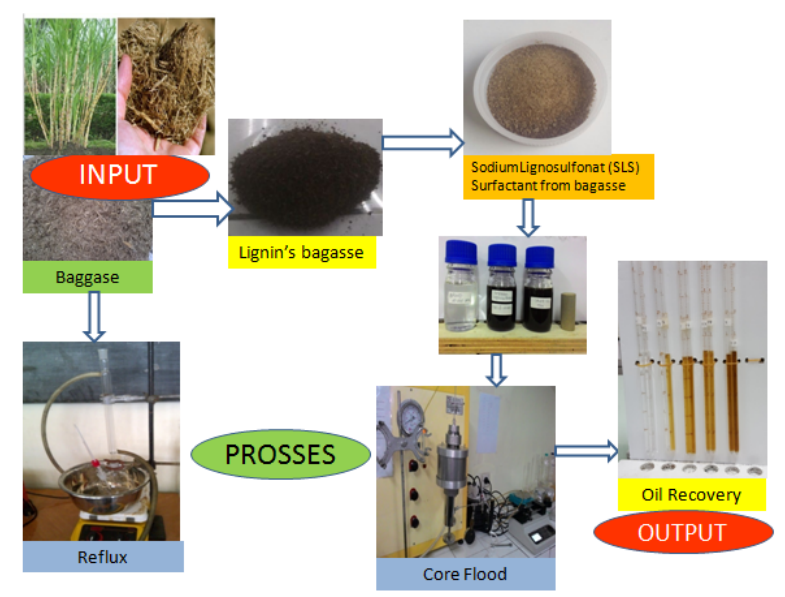

Fig. 3. Process activity of bagasse into SLS surfactant and its application in EOR process.

\section{Result}

The FTIR test on lignin isolation shows that bagasse lignin contains $\mathrm{O}-\mathrm{H}$ phenolic functional group, aliphatic and aromatic group - $\mathrm{CH}-, \mathrm{C}=\mathrm{O}$ group, arena-functional group $-\mathrm{C}=\mathrm{C}-$, amine $\mathrm{C}-\mathrm{N}$ groups and alkyl $\mathrm{C}-\mathrm{H}$ groups. - The results of comparing bagasse lignin with the commercial standard lignin of Aldrich and Kraft products show that the bagasse has the same qualification as the standard lignin, so it supports the option to continue to the next stage, ie sulfonation process.

The results of the FTIR test on the sodium lignosulfonates from bagasse show that it contains components comprising of $\mathrm{C}=\mathrm{C}$ alkene, $\mathrm{S}=\mathrm{O}$ sulphat, $\mathrm{C}=\mathrm{O}$ carboxylic acids and S-OR esters elements, with wavelength spectral values approaching standard wavelength spectrum. From table 1 showed that FTIR results and comparisons with existing standard products, both in lignin and lignosulfonates, suggest that the isolation lignin and sulfonation processes is complete and comparable with standard products. 
Table 1. Componen of SLS surfactant's bagasse.

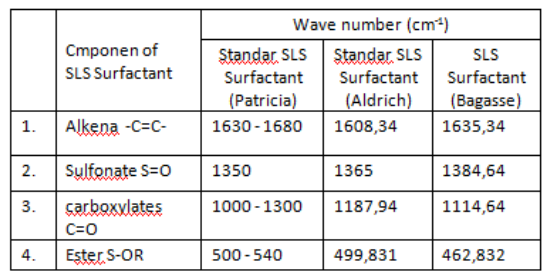

The calculation of Hydropilic-Lipophilic Balance (HLB) values of sodium lignosulfonates surfactant from bagasse shows HLB value of 11.62 which means the product is qualified as Oil-Water emulsion, therefore can function as emulsion-forming fluid.

Table 2.Characteristics of SLS surfactant's bagasse.

\begin{tabular}{|l|l|}
\hline The empirical formula & $\left(\mathrm{C}_{11} \mathrm{H}_{16} \mathrm{O}_{S} \mathrm{~S}\right)_{n}$ \\
\hline \multirow{4}{*}{$\begin{array}{l}\text { Component of SLS } \\
\text { Surfactant }\end{array}$} & Alkena $-\mathrm{C}=\mathrm{C}-$ \\
\cline { 2 - 2 } & Sulfonate $\mathrm{S}=\mathrm{O}$ \\
\cline { 2 - 2 } & sarboxxlates $\mathrm{C}=\mathrm{O}$ \\
\cline { 2 - 2 } & Ester. S-OR \\
\hline Molecular weight & 308.06 \\
\hline HLB & 11.62 \\
\hline
\end{tabular}

The characterization test of the sodium lignosulfonates surfactant from bagasse (SLS surfactant's bagasse) at various concentrations and brine salinities shows that it is stable in the aqueous stability test, forming the middle-phase emulsion (microemulsion) with light oil component and having a stable $1-10 \%$ microemulsion. With light oil, surfactant has IFT value range from 6.81 - $1.091 \mathrm{mN} / \mathrm{m}$. The adsorption of the surfactant on the core surface ranges from $77.78-205.33 \mathrm{mg} / \mathrm{g}$, and the wettability test showes contact angle ranging from $28^{\circ}$ $48^{\circ}$.

Table 3. The result characterization test of the SLS surfactant's bagasse and the result of injection core

\begin{tabular}{|c|c|c|r|c|c|c|c|}
\hline No. & $\begin{array}{c}\text { Salinity } \\
(\mathrm{ppm})\end{array}$ & $\begin{array}{c}\text { Surfactant } \\
\text { concentration } \\
(\%)\end{array}$ & $\begin{array}{c}\text { Micro } \\
\text { emulssion } \\
(\%)\end{array}$ & $\begin{array}{c}\text { IFT } \\
(\mathrm{mN} / \mathrm{m})\end{array}$ & $\begin{array}{c}\text { Thermal } \\
\text { stability }\end{array}$ & $\begin{array}{c}\mathrm{RF} \\
\mathrm{WF} \\
(\%)\end{array}$ & $\begin{array}{c}\mathrm{RF} \\
\mathrm{SF} \\
(\%)\end{array}$ \\
\hline 1. & 5.000 & 1.5 & 1.25 & 6.810 & Unstabel & 31.00 & 7.00 \\
\hline 2. & 10.000 & 1.5 & 10.00 & 2.728 & Stabel & 16.00 & 9.25 \\
\hline 3. & 10.000 & 3.0 & 7.50 & 1.675 & Stabel & 24.00 & 9.50 \\
\hline 4. & 20.000 & 1.5 & 5.00 & 4.131 & Stabel & 20.00 & 8.55 \\
\hline 5. & 20.000 & 4.5 & 0.00 & 1.272 & Stabel & 21.00 & 1.05 \\
\hline 6. & 40.000 & 1.5 & 6.00 & 4.107 & Unstabel & 20.00 & 1.80 \\
\hline 7. & 40.000 & 4.0 & 0.00 & 2.724 & Unstabel & 20.08 & 1.16 \\
\hline 8. & 80.000 & 1.5 & 1.25 & 3.614 & Stabel & 18.00 & 10.71 \\
\hline 9. & 80.000 & 4.0 & 1.00 & 1.091 & Unstabel & 20.00 & 5.60 \\
\hline
\end{tabular}

The final test result, which is injection of with sodium lignosulfonates surfactant into a synthetic core containing light oil shows an oil gain of $1.05-10.71 \%$ which is also done at various concentrations of dissolved sodium lignosulfonates surfactant at various brine salinities.

\section{Conclusion}

1. Bagasse into lignosulfonates process is done in two stages: lignin separation process from bagasse (isolation process) and lignin sulfonation process into lignosulfonates

2. The lignosulfonates is complete and comparable with standard products and therefore can be used as injection fluid .
3. Sodium lignosulfonates surfactant of bagasse shows HLB value of 11.61 which means the product is classified as $\mathrm{O} / \mathrm{W}$ emulsion, therefore can function as emulsion-forming fluid.

4. Characterization of sodium lignosulfonates surfactant shows that it is stable in the aqueous stability test, forming the middle-phase emulsion (microemulsion) with light oil component and having a stable $1-10 \%$ volume microemulsion, has an IFT value range from $6.81-1.091 \mathrm{mN} / \mathrm{m}$.

5. Sodium lignosulfonates surfactant injection into synthetic core containing light oil gives an increase of oil recovery of $1.05-10.71 \%$.

6. The innovation to process bagasse into sodium lignosulfonates surfactant which has been completed involves two scientific application fields, chemistry and petroleum engineering to increase oil production from a reservoir. This innovation process should be optimized gradually and continuously in order to obtain maximum results.

This research was facilitated by the Research Consortium OGRINDO at ITB, Trisakti University, and the Indonesian Directorate General of Higher Education Decentralization Fund for PUPT Fund 2014 Usakti - Dikti, Decentralization Fund 2014 ITB, PUPT Fund 2015 ITB - Dikti and PUPT Fund 2016 ITB Dikti. We also thank to Astechnova 2017 who publishes this article, which in turn will benefit the society.

\section{References}

1. Chakar, Review of Current and Future Softwood Kraft Lignin Process Chemistry, International Lignin Institute Conference, 131 - 141 (2004)

2. J. F. Craig, The Reservoir Engineering Aspects Of Waterflooding, Tulsa: Society of Petroleum Engineers (1993)

3. O. ElMofty, Surfactant enhanced oil recovery by wettability alteration in sandstone reservoirs, Missourri University of Science and Technology, Missouri: Student Research \& Creative Works at Scholars' Mine (2012)

4. D. Fengel, G. Wegener, Wood: Chemistry, Ultrastructure, Reactions, Berlin: Walter de Gruyter (1989)

5. T. Fujimoto, New Introduction to Surface Active Agent, Kyoto: Sanyo Chemical Industri (1985)

6. D.W. Green, G. Willhite, Enhanced Oil Recovery, Texas: SPE textbook (1998)

7. E. Hambali, Proses Pembuatan Surfaktan Metil Ester Sulfonat (MES) Untuk Aplikasi Industri Migas, IPB, Surfactant and Bioenergi Research Centre (2008)

8. L. L.Schramm, Surfactant: Fundamentals andApplication in the Petroleum Industry, Cambrigde: University of Cambrige (2000)

9. Lacey, Moulding of Sugar Cane Bagasse, Annals of Applied Biology, 76(1), 63-76 (1974)

10. L. Lake, Enhanced Oil Recovery, Austin: University of Texas (2003)

11. D. Myers, Surfactant Science and Technology, New Yersey: Wiley Interscience (2006) 
12. R. J. Patricia, Relationship between the structure of Fe-Lignosulfonate complexes determined by FTIR spectroscopy and their reduction by the leaf $\mathrm{Fe}$ reductase, The Proceedings of the International Plant Nutrition Colloquium XVI, hal.1 (2009) 